\title{
PENGARUH LATIHAN FISIK MELALUI PENDEKATAN MODEL LATIHAN BERMAIN DAN LATIHAN SIRKUIT TERHADAP KAPASITAS AEROBIK MAKSIMAL
}

\author{
(Studi Eksperimen Pada Mahasiswa FIK Universitas Negeri Padang) \\ Umar $^{1}$, Alnedral $^{1}$ \\ ${ }^{1}$ Faculty of Sports Science, Universitas Negeri Padang \\ 1umarmardesia@gmail.com, alnedral@uny.ac.id
}

\begin{abstract}
Abstrak
Tujuan

Tujuan penelitian ini adalah untuk menganalisa pengaruh model latihan yang efektif dan efisien terhadap peningkatan kapasitas aerobik maksimal.

Metode

Jenis penelitian ini termasuk eksperimen semu, dengan perlakuan berupa model latihan bermain dan model latihan sirkuit. Sebelum diberikan perlakuan, terlebih dahulu dilakukan pre-test (tes awal) tentang Kapasitas Aerobik Maksimal dengan menggunakan instrumen MSFT (Bleep test). Perlakuan diberikan sebanyak 16 kali dengan rincian 3 kali latihan perminggu. Populasi target adalah mahasiswa FIK Universitas Negeri Padang, sedangkan populasi terjangkau adalah mahasiswa FIK Universitas Negeri Padang program studi Pendidikan Kepelatihan Olahraga angkatan 2013/2014 sebanyak 30 orang. Pengambilan sampel dilakukan secara purposive sampling. Analisis data menggunakan statistik deskriptif dan inferensial, statistik inferensial menggunakan uji t pada taraf signifikansi $\alpha 0.05$.
\end{abstract}

Hasil

1. Model latihan bermain memberikan pengaruh secara signifikan terhadap peningkatan Kapasitas Aerobik Maksimal mahasiswa FIK Universitas Negeri Padang, $(\rho=0,000<\alpha 0,05)$.

2. Model latihan sirkuit memberikan pengaruh yang signifikan terhadap peningkatan Kapasitas Aerobik Maksimal mahasiswa FIK Universitas Negeri Padang, $(\rho=0,000<\alpha 0,05$.

3. Terdapat perbedaan pengaruh yang signifikan antara model latihan bermain dengan model latihan sirkuit terhadap peningkatan Kapasitas Aerobik Maksimal mahasiswa FIK Universitas Negeri Padang, $(\rho=0,001<\alpha 0,05)$.

Kesimpulan

Kedua model latihan yang merupakan perlakuan dalam penelitian ini memberikan efek yang positif terhadap peningkatan kapasitas aerobik maksimal. Naman hasil analisis data menunjukkan bahwa model latihan sirkuit lebih efektif untuk meningkatkan kapasitas aerobik maksimal.

Kata Kunci; model latihan bermain, model latihan sirkuit, kapasitas aerobik maksimal

\section{Pendahuluan}

Melahirkan atlet berprestasi, memerlukan perencanaan yang matang, serta pembinaan yang berjenjang. Dalam Undang-Undang RI No. 3 tahun 2005, tentang Sistem Keolahragaan Nasional, dalam Bab V pasal 33 ayat 2 disebutkan bahwa; "Olahraga prestasi adalah olahraga yang membina dan mengembangkan olahragawan secara terencana, berjenjang dan berkelanjutan melalui latihan dan kompetisi untuk mencapai prestasi dengan dukungan ilmu pengetahuan dan teknologi keolahragaan.[10]. Berdasarkan kutipan tersebut dapat disimpulkan bahwa; untuk melahirkan atlet berprestasi perlu melakukan pembinaan yang terencana dengan dukungan ilmu pengetahuan dan teknologi, agar proses pelatihan bisa dimaksimalkan sesuai dengan fungsi organ tubuh secara fisiologis. Tanpa melibatkan ilmu pengetahuan dan teknologi di dalam proses latihan, maka kemampuan atlet tidak bisa ditingkatkan secara maksimal. 
Pembinaan yang dilakukan tersebut salah satunya melalui latihan, karena dengan latihan bisa membantu atlet meningkatkan keterampilan dan prestasinya terutama terhadap empat aspek seperti; teknik, kondisi fisik, taktik dan strategi, serta mental". Apabila salah satu dari aspek tersebut lemah, maka akan berpengaruh terhadap aspek yang lain, sehingga berakibat atlet tidak bisa tampil maksimal dalam setiap pertandingan. [3]

Salah satu aspek penting yang harus dimiliki oleh seorang atlet, yaitu aspek kondisi fisik yang merupakan aspek mendasar untuk mendukung aspek yang lain. Elemen kondisi fisik tersebut seperti; kekuatan, kecepatan, dayatahan, kelentukan, kelincahan, dayaledak, keseimbangan dan koordinasi. Elemen kondisi fisik mana yang harus dimiliki oleh seorang atlet, itu tergantung dari cabang olahraga yang diikutinya, karena masing-masing cabang olahraga memiliki karakteristik tersendiri. [1]

Pada cabang olahraga dayatahan seperti; lari jarak menengah sampai jarak jauh, renang nomor 100 meter lebih, cabang-cabang olahraga bela diri dan lain-lain, dayatahan merupakan komponen fisik utama yang harus dimiliki, terutama dayatahan aerobik, karena untuk mampu melakukan aktivitas dalam waktu yang relatif lama, diperlukan dayatahan aerobik. Dayatahan aerobik, yaitu kemampuan tubuh melakukan aktivitas dalam waktu yang lama tanpa mengalami kelelahan yang berarti dengan memakai pasok energi aerobik.

Dayatahan aerobik atau sering disebut dengan cardio-respiratory endurance adalah suatu kualitas bagaimana tubuh dengan baik secara keseluruhan mendukung aktivitas fisik dan dapat menghambat penyebab dari kelelahan". [6]. Sedangkan Robert Hoccey (1981) mengatakan bahwa; "Cadiovasculer endurance dapat diartikan sebagai kemampuan untuk melakukan kerja terus menerus dalam melakukan tugas sekelompok otot pada waktu yang relatif lama.[8]. Tinggi rendahnya tingkat dayatahan aerobik ini, akan dipengaruhi oleh tinggi rendahnya tingkat $\mathrm{VO}_{2} \max$ atau dikenal dengan kapasitas aerobik maksimal. Tinggi rendahnya kapasitas aerobik maksimal dipengaruhi oleh komponen organis seperti; paru-paru, jantung, pembuluh darah, dan kualitas darah (hemoglobin) serta otot rangka yang akan mengkonsumsi oksigen untuk proses metabolisme energi secara aerobik, sehingga menghasilkan energi untuk kerja sel, termasuk sel otot.[9].

Kapasitas aerobik maksimal $\left(\mathrm{VO}_{2} \max\right.$ ) yang tinggi, tidak hanya diperlukan oleh atlet pada saat dia latihan maupun bertanding saja, tetapi juga diperlukan pada saat mereka melakukan pemulihan (recovery). Kekalahan yang sering dialami oleh seorang atlet dalam suatu pertandingan, salah satunya disebabkan oleh rendahnya kapasitas aerobik maksimal mereka, hal ini dapat dilihat dalam setiap pertandingan misalnya cabang beladiri.[9]. Pada umumnya atlet tampil prima dan beringas pada babak (ronde-ronde) awal, tapi pada ronde berikutnya, kecenderungan kemampuan mereka terutama dayatahan mulai menurun, hal ini merupakan bukti bahwa mereka tidak didukung oleh kapasitas aerobik maksimal $\left(\mathrm{VO}_{2} \mathrm{max}\right)$ yang tinggi, sehingga proses pemulihan (recovery) menjadi tidak berjalan sempurna.

Berdasarkan observasi yang dilakukan pada mahasiswa FIK Universitas Negeri Padang, ternyata masih banyak mahasiswa yang memiliki kapasitas aerobik maksimal yang rendah. Hal ini tergambar dari setiap mengikuti kuliah praktek, maupun melakukan latihan, banyak di antara mahasiswa yang mengalami kelelahan yang lebih cepat, pada hal kegiatan yang dilakukan belum maksimal. Rendahnya tingkat kapasitas aerobik maksimal mahasiswa FIK Universitas Negri Padang, yang nota bene sedang dipersiapkan sebagai seorang sarjana kepelatihan yang akan bertugas dilapangan sesuai dengan profesinya sebagai seorang pelatih. Disamping itu, mahasiswa FIK Universitas Negeri Padang sebagian besar merupakan atlet yang masih aktif mengikuti berbagai iven pertandingan, baik iven Pekan Olahraga Provinsi (Porvrop), Kejuaraan Nasional (Kejurnas), Pekan Olahraga Nasional (PON), maupun kejuaraan regional seperti SEA Games, tentu disebabkan oleh banyak faktor, salah satunya adalah materi dari program latihan yang diberikan pelatih mungkin belum tepat sasaran sesuai tujuan latihan.

Berdasarkan uraian di atas, maka peneliti tertarik untuk melakukan penelitian tentang "Pengaruh latihan fisik melalui pendekatan model latihan bermain dan model latihan sirkuit terhadap kapasitas aerobik maksimal“. Dengan adanya penelitian ini diharapkan dapat menemukan jenis latihan yang lebih efektif dan efisien dalam meningkatkan kapasitas aerobik maksimal.

\section{Rumusan Masalah}

Adapun rumusan masalah adalah; 
1. Apakah model latihan bermain bisa meningkatkan kapasitas aerobic maksimal ?

2. Apakah model latihan sirkuit bisa meningkatkan kapasitas aerobic maksimal ?

3. Apakah terdapat perbedaan pengaruh antara model latihan bermain dan model latihan sirkuit terhadap peningkatan kapasitas aerobic maksimal ?

\section{Tujuan penelitian;}

Tujuan penelitian ini adalah untuk menganalisa;

1. Pengaruh model latihan bermain terhadap kapasitas aerobic maksimal,

2. Pengaruh model latihan sirkuit terhadap kapasitas aerobic maksimal,

3. Perbedaan pengaruh antara model latihan bermain dengan model latihan sikuit terhadap kapasitas aerobic maksimal.

\section{Manfaat Penelitian}

Adapun manfaat penelitian adalah sebagai berikut;

1. Pelatih, sebagai pedoman dalam pembuatan program latihan fisik,

2. Mahasiswa/Atlet, sebagai pengetahuan dalam melaksanakan latihan fisik yang benar,

3. Peneliti, menambah wawasan IImu Pengetahuan dan Teknologi dalam menunjang profesi sebagai tenaga pendidik dan pelatih.

\section{Metodologi}

Jenis penelitian adalah eksperimen semu (quasi experiment). Eksperimen semu (quasi experiment) adalah jenis penelitian eksperimen dimana si peneliti tidak dapat mengendalikan secara penuh semua variabel yang kemungkinan dapat berpengaruh terhadap variabel terikat.[2]

Penelitian dilakukan di laboratorium Fakultas IImu Keolahragaan Universitas Negeri Padang. Proses pengumpulan data dilakukan dalam 2 (dua) tahapan utama. Tahap pertama pengumpulan data tentang kapasitas aerobik maksimal. Tahap kedua adalah pemberian perlakuan model latihan bermain dan model latihan sirkuit sebanyak 16 kali latihan, (3 kali perminggu).

Rancangan penelitian ini adalah; the two group pre test and post test design. Populasi dalam penelitian ini, adalah mahasiswa FIK Universitas Negeri Padang sebagai populasi target (target population). Sedangkan populasi terjangkau (affordable population) adalah mahasiswa FIK Negeri Padang program studi Pendidikan Kepelatihan Olahraga angkatan 2013/2014 yang terdaftar pada semester Juli - Desember 2013/2014. Sedangkan sampel yang digunakan dalam penelitian ini sebanyak 30 orang mahasiswa putra dengan teknik purposive sampling.

Instrumen penelitian untuk mengukur kapasitas aerobic maksimal adalah Bleep test (MSFT). Analisis data menggunakan uji t dengan taraf signifikansi $\alpha=0,05$.

\section{Hasil Penelitian}

\section{A. Deskripsi Data}

\section{Data Awal Kapasitas Aerobik Maksimal Kelompok Metode Latihan Bermain}

Berdasarkan hasil analisis data deskriptif dari 15 orang kelompok metode latihan bermain, diperoleh skor tertinggi 47.1 , skor terendah 30.6, rerata skor 37.7, rentangan 16.5. Untuk lebih jelasnya dapat dilihat pada tabel berikut:

Tabel 1. Data Awal Kapasitas Aerobik Maksimal Kelompok Metode Latihan Bermain

\begin{tabular}{|c|c|c|c|}
\hline No & Kelas Interval & (Fa) & (Fr) \\
\hline 1 & $30.6-33.4$ & 4 & 27 \\
\hline 2 & $33.5-35.7$ & 2 & 13 \\
\hline 3 & $35.8-38.5$ & 2 & 13 \\
\hline 4 & $38.6-41.2$ & 4 & 27 \\
\hline 5 & $41.3-47.5$ & 3 & 20 \\
\hline & Jumlah & 15 & $100 \%$ \\
\hline
\end{tabular}




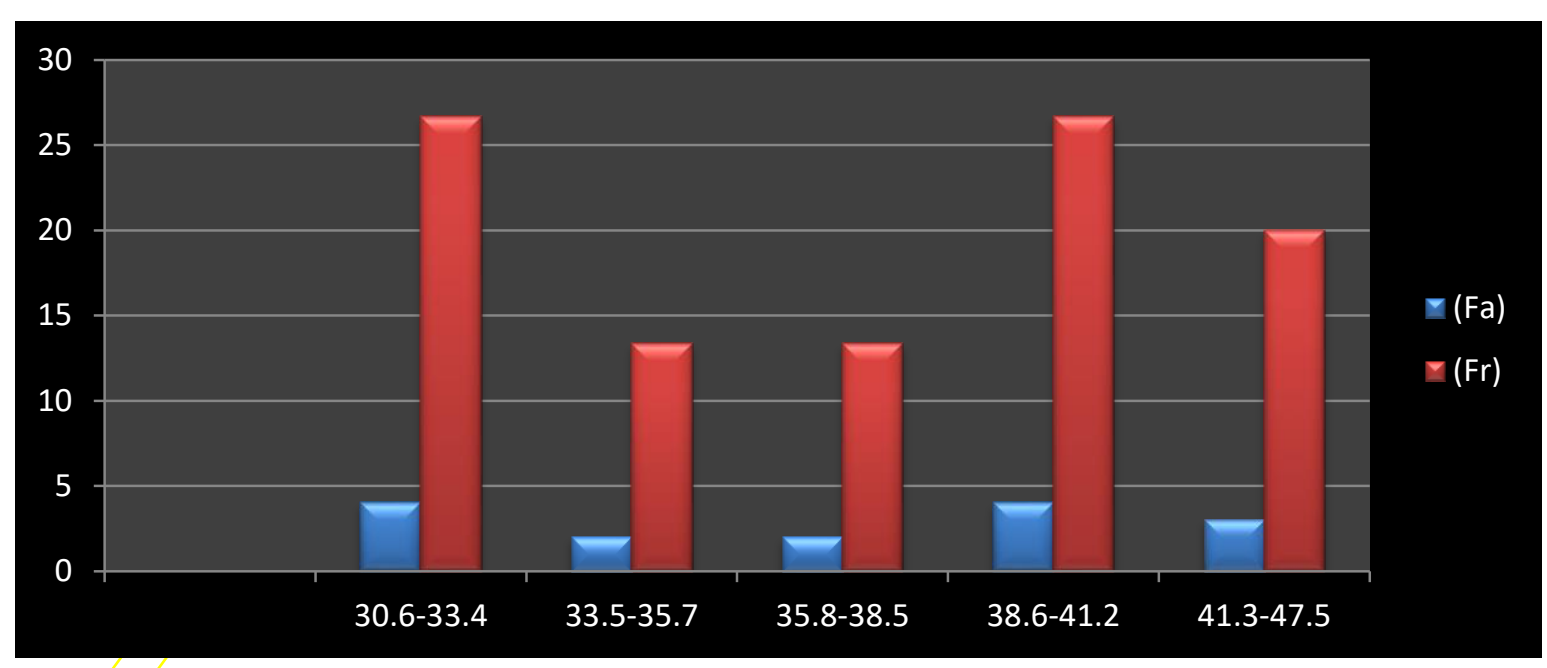

Gambar 1. Histogram frekuensi skor Kapasitas Aerobik Maksimal kelompok Metode Latihan Bermain

\section{Data Awal Kapasitas Aerobik Maksimal Kelompok Metode Latihan Sirkuit}

Berdasarkan hasil analisis data deskriptif dari 15 orang kelompok metode latihan bermain, diperoleh skor tertinggi 46.8, skor terendah 30.6, rerata skor 37.7, rantangan 16.2 dan standar deviasi 5.03. Untuk lebih jelasnya dapat dilihat pada tabel berikut:

Tabel 2. Data Awal Kapasitas Aerobik Maksimal Kelompok Metode Latihan Sirkuit

\begin{tabular}{|c|c|c|c|}
\hline No & Kelas Interval & (Fa) & (Fr) \\
\hline 1 & $30.6-33.4$ & 3 & 20 \\
\hline 2 & $33.5-35.7$ & 4 & 27 \\
\hline 3 & $35.8-39.5$ & 2 & 13 \\
\hline 4 & $39.6-41.2$ & 3 & 20 \\
\hline 5 & $41.3-46.8$ & 3 & $100 \%$ \\
\hline & Jumlah & 15 & \\
\hline
\end{tabular}

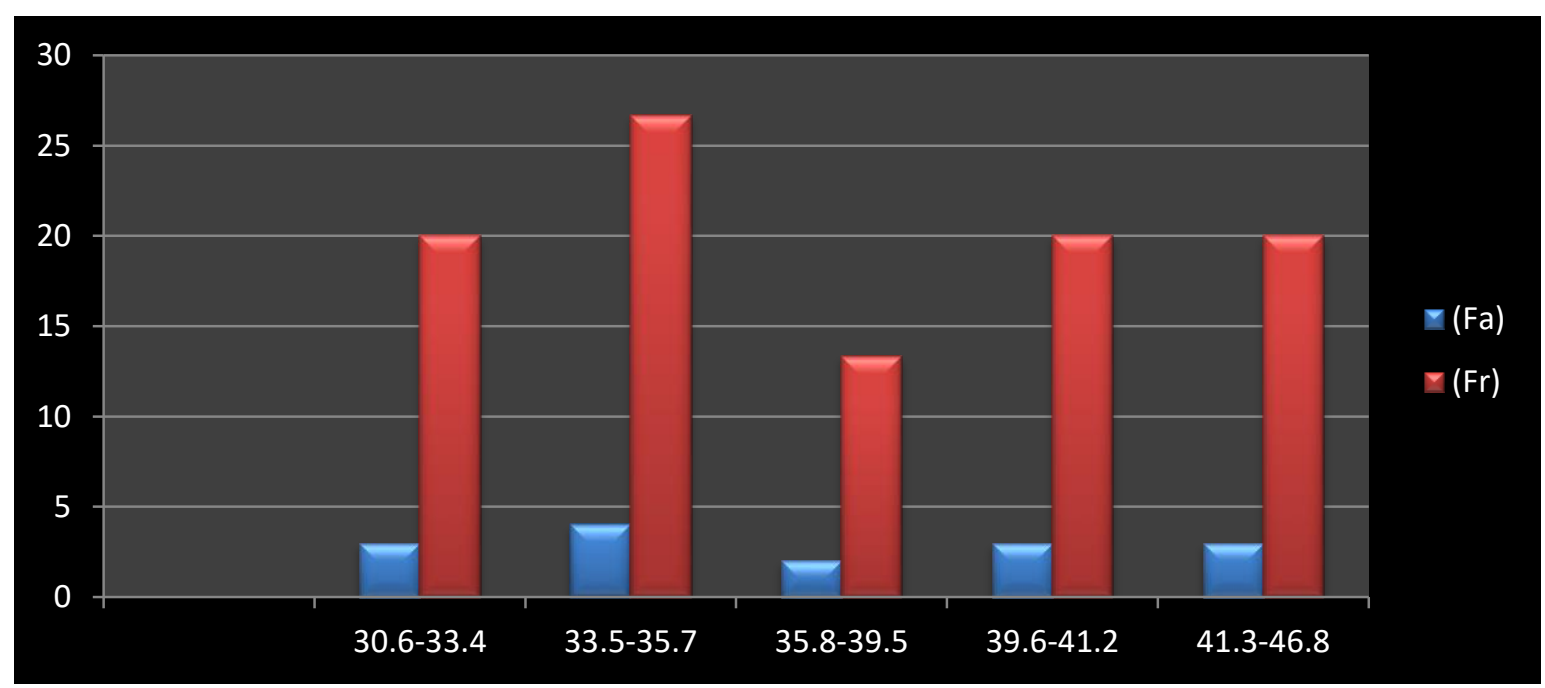

Gambar 2. Histogram frekuensi skor Kapasitas Aerobik Maksimal kelompok Metode Latihan Bermain 
3. Data Akhir Kapasitas Aerobik Maksimal Kelompok Metode Latihan Bermain

Berdasarkan hasil analisis data deskriptif dari 15 orang kelompok metode latihan bermain, diperoleh skor tertinggi 48.4, skor terendah 32.5, rerata skor 38.8, rantangan 15.9 dan standar deviasi 4.67. Untuk lebih jelasnya dapat dilihat pada tabel berikut:

Tabel 3. Data Akhir Kapasitas Aerobik Maksimal Kelompok Metode Latihan Bermain

\begin{tabular}{|c|c|c|c|}
\hline No & Kelas Interval & (Fa) & (Fr) \\
\hline 1 & $32.9-35.6$ & 4 & 27 \\
\hline 2 & $35.7-38.4$ & 2 & 13 \\
\hline 3 & $38.5-40.3$ & 3 & 20 \\
\hline 4 & $40.4-42.7$ & 3 & 20 \\
\hline 5 & $42.8-48.5$ & 3 & 20 \\
\hline & Jumlah & 15 & $100 \%$ \\
\hline
\end{tabular}

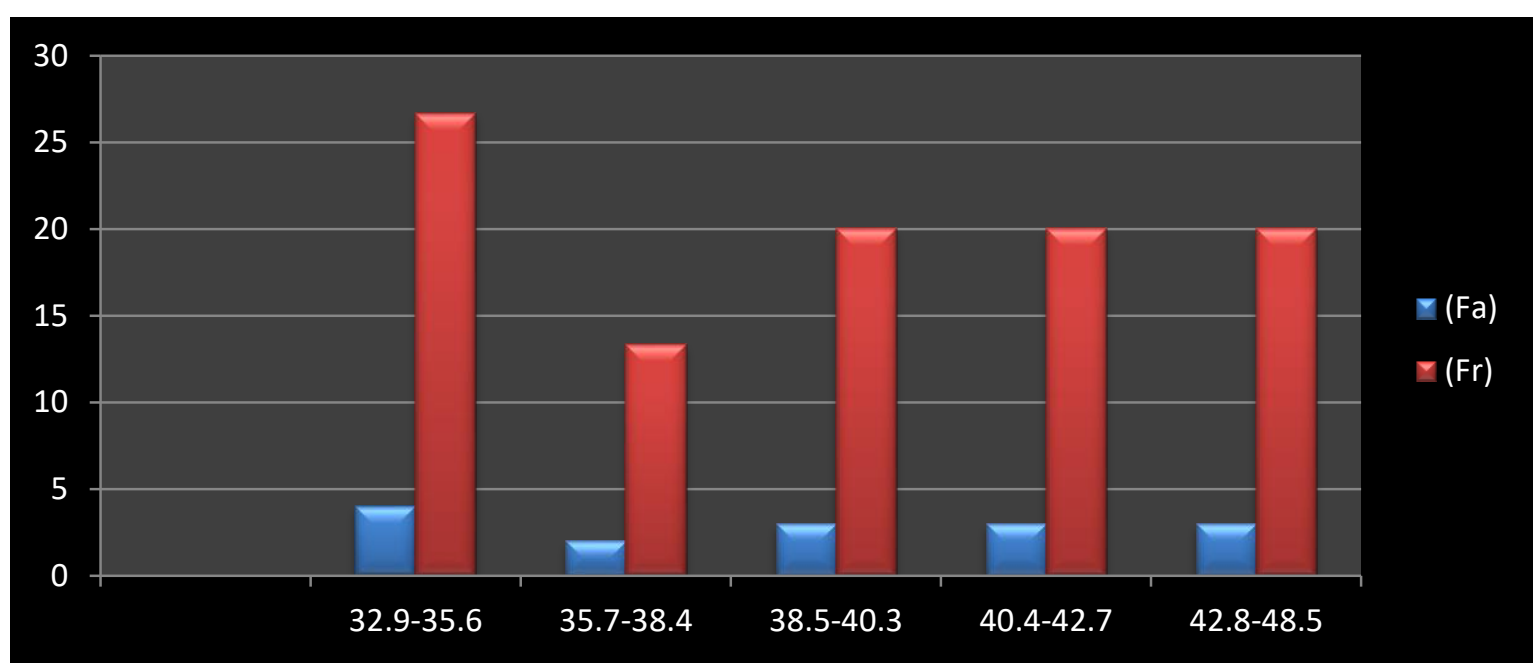

Gambar 3. Histogram frekuensi skor Kapasitas Aerobik Maksimal kelompok Metode Latihan Bermain

\section{Data Akhir Kapasitas Aerobik Maksimal Kelompok Metode Latihan Sirkuit}

Berdasarkan hasil analisis data deskriptif dari 15 orang kelompok metode latihan sirkuit, diperoleh skor tertinggi 49.0, skor terendah 34.3, rerata skor 40.6, rantangan 14.7 dan standar deviasi 4.56. Untuk lebih jelasnya dapat dilihat pada tabel berikut:

Tabel 4. Data Akhir Kapasitas Aerobik Maksimal Kelompok Metode Latihan Sirkuit

\begin{tabular}{|c|c|c|c|}
\hline No & Kelas Interval & (Fa) & (Fr) \\
\hline 1 & $34.3-35.8$ & 3 & 20 \\
\hline 2 & $35.9-37.6$ & 1 & 7 \\
\hline 3 & $37.7-40.4$ & 3 & 20 \\
\hline 4 & $40.5-42.7$ & 3 & 20 \\
\hline 5 & $42.8-50.00$ & 5 & 33 \\
\hline & Jumlah & 15 & $100 \%$ \\
\hline
\end{tabular}




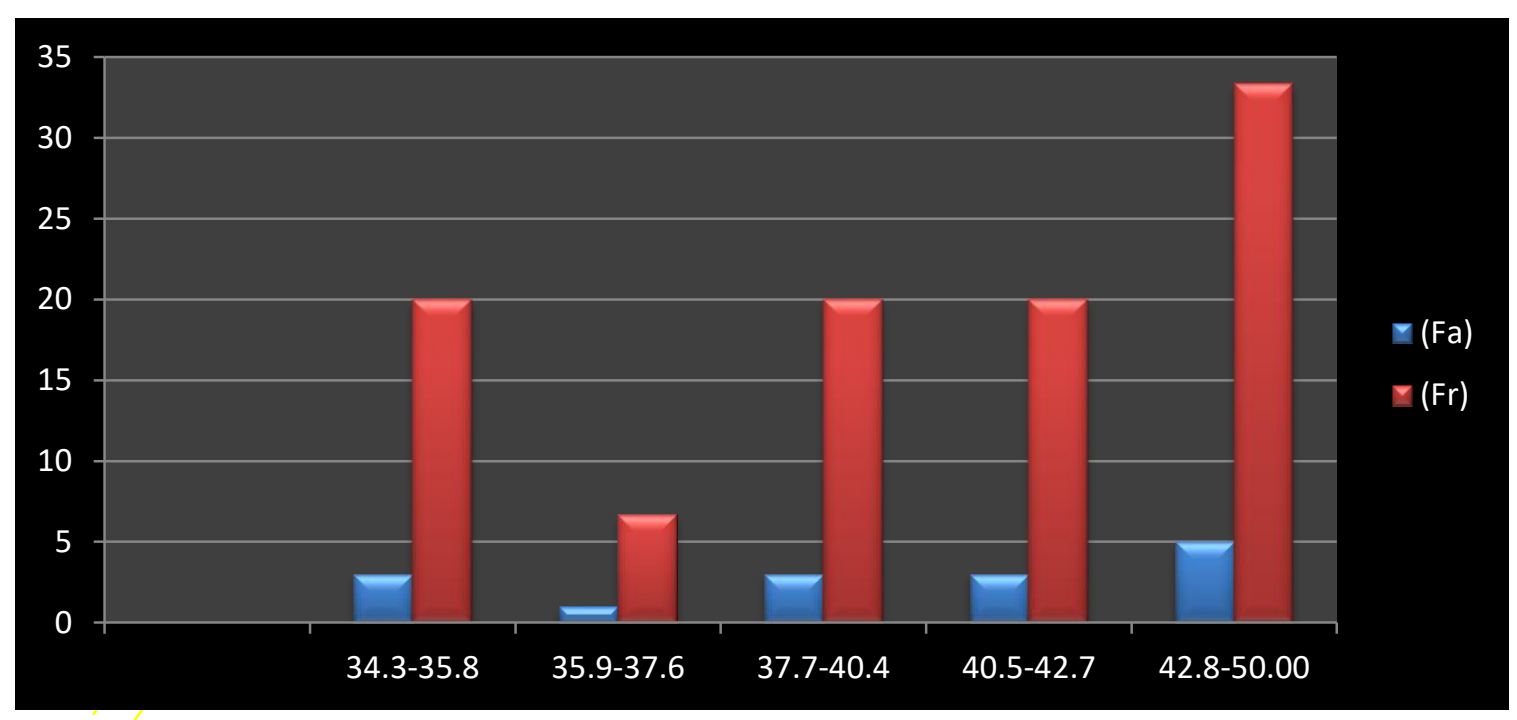

Gambar 4. Histogram frekuensi skor Kapasitas Aerobik Maksimal kelompok Metode Latihan Bermain

\section{B. Pengujian Hipotesis}

\section{Hipotesis Pertama}

Hipotesis yang diajukan dalam penelitian ini dalah "Terdapat pengaruh model latihan bermain terhadap kapasitas aerobik masimal. Berdasarkan hasil analisis data ternyata $\rho=0,000<\alpha=$ 0,05 . Dengan demikian dapat disimpulkan bahwa terdapat pengaruh metode latihan bermain terhadap kapasitas aerobik makismal atlet. Untuk lebih jelasnya dapat dilihat pada tabel berikut;

Tabel 5. Hasil Analisis Uji t Data Pretest dan Posttest Kelompok Bermain

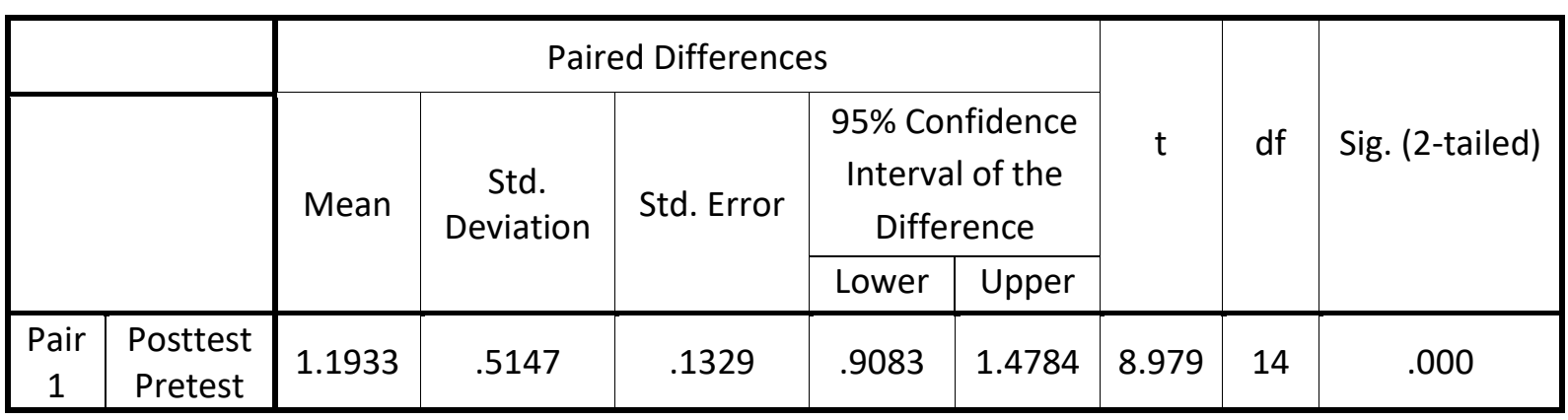

Dengan demikian hipotesis yang diajukan dalam penelitian ini yang mengatakan terdapat pengaruh metode latihan bermain terhadap kapasitas aerobik makismal atlet dapat diterima.

\section{Hipotesis Kedua}

Hipotesis yang diajukan dalam penelitian ini dalah "Terdapat pengaruh model latihan Sirkuit terhadap kapasitas aerobik masimal. Berdasarkan hasil analisis data ternyata $\rho=0,000<\alpha 0,05$. Dengan demikian dapat disimpulkan bahwa terdapat pengaruh metode latihan sirkuit terhadap kapasitas aerobik makismal atlet. Untuk lebih jelasnya dapat dilihat pada tabel berikut; 
Tabel 6. Hasil Analisis Uji t Data Pretest dan Posttest Kelompok Sirkuit

\begin{tabular}{|c|c|c|c|c|c|c|c|c|c|}
\hline & & & Pair & d Differenc & & & & & \\
\hline & & Mean & $\begin{array}{c}\text { Std. } \\
\text { Deviation }\end{array}$ & Std. Error & $\begin{array}{r}95 \% \text { Co } \\
\text { Interva } \\
\text { Diffe }\end{array}$ & $\begin{array}{l}\text { fidence } \\
\text { I of the } \\
\text { rence }\end{array}$ & $\mathrm{t}$ & $\mathrm{df}$ & Sig. (2-tailed) \\
\hline & & & & & Lower & Upper & & & \\
\hline $\begin{array}{c}\text { Pair } \\
1\end{array}$ & $\begin{array}{c}\text { Posttest } \\
\text { Pretest }\end{array}$ & 2.9000 & .7521 & . 1942 & 2.4835 & 3.3165 & $\begin{array}{c}14.93 \\
3\end{array}$ & 14 & .000 \\
\hline
\end{tabular}

Dengan demikian hipotesis yang diajukan dalam penelitian ini yang mengatakan terdapat pengaruh metode latihan sirkuit terhadap kapasitas aerobik makismal atlet dapat diterima.

\section{Hipotesis Ketiga}

Hipotesis yang diajukan dalam penelitian ini dalah "Terdapat perbedaan pengaruh antara model latihan bermain dan model latihan sirkuit terhadap kapasitas aerobik masimal. Berdasarkan hasil analisis data ternyata $\rho=0,001<\alpha 0,05$. Dengan demikian dapat disimpulkan bahwa terdapat perbedaan pengaruh antara metode latihan bermain dan metode latihan sirkuit terhadap kapasitas aerobik makismal atlet. Untuk lebih jelasnya dapat dilihat pada tabel berikut;

Tabel 7. Hasil Analisis Uji t Data Posttest antara Kelompok Bermain dan Kelompok Sirkuit

\begin{tabular}{|c|c|c|c|c|c|c|c|c|c|}
\hline & & \multicolumn{5}{|c|}{ Paired Differences } & \multirow{3}{*}{$\mathrm{t}$} & \multirow{3}{*}{$d f$} & \multirow{3}{*}{ Sig. (2-tailed) } \\
\hline & & \multirow[t]{2}{*}{ Mean } & \multirow[t]{2}{*}{$\begin{array}{c}\text { Std. } \\
\text { Deviation }\end{array}$} & \multirow[t]{2}{*}{ Std. Error } & \multicolumn{2}{|c|}{$\begin{array}{l}\text { 95\% Confidence } \\
\text { Interval of the } \\
\text { Difference }\end{array}$} & & & \\
\hline & & & & & Lower & Upper & & & \\
\hline $\begin{array}{c}\text { Pair } \\
1\end{array}$ & $\begin{array}{c}\text { Posttest } \\
\text { Sirkuit } \\
\text { Posttest } \\
\text { Bermain }\end{array}$ & 1.6571 & 1.3971 & .3734 & .8505 & 2.4638 & 4.438 & 13 & .001 \\
\hline
\end{tabular}

Dengan demikian hipotesis yang diajukan dalam penelitian ini yang mengatakan terdapat perbedaan pengaruh antara metode latihan bermain dan metode latihan sirkuit terhadap kapasitas aerobik makismal atlet dapat diterima, dan jika dilihat dari perbedaan skor rata-rata (mean), maka model latihan sirkuit lebih efektif untuk meningkatkan kapasitas aerobic maksimal.

C. Pembahasan

\section{Pengaruh Model Latihan Bermain Terhadap Kapasitas Aerobik Maksimal}

Hasil analisis data yang di lakukan dalam penelitian ini ternyata $\rho=0,000<\alpha 0,05$. Artinya, model latihan bermain dapat meningkatkan kapasitas aerobik maksimal secara bermakna. Peningkatan kapasitas aerobik maksimal sebagai efek latihan tersebut, kemungkinan disebabkan oleh beberapa faktor sebagai berikut; Pertama, Intensitas latihan rata-rata $70 \%-80 \%$ dari denyut nadi maksimal. Intensitas tersebut sudah masuk ke zona latihan untuk meningkatkan kapasitas aerobik maksimal ( $\mathrm{VO}_{2}$ maks). Hal ini sebagaiman yang dikatakan oleh; Matt Fitzgerald bahwa; Research suggests that vigorous-intensity exercise (60-84\% oxygen consumption reserve (VO2R)) results in greater increases in aerobic capacity than moderate-intensity exercise (40-59\% VO2R). [6]

Penelitian menunjukkan bahwa intensitas latihan yang kuat/tinggi $(60-84 \%$ dari konsumsi oksigen cadangan (V'O2R)) menghasilkan peningkatan yang lebih besar dalam kapasitas aerobik dari 
pada intensitas latihan sedang (40-59\% V'O2R). Hal ini diperkuat oleh Lanty O'Connor, (2009) bahwa efek latihan dayatahan untuk meningkatkan kapasitas aerobik maksimal $\left(\mathrm{VO}_{2}\right.$ max) sudah dapat terjadi pada intensitas latihan $70 \%$. Untuk lebih jelasnya dapat dilihat pada tabel 4 .

Tabel 8. Zona intensitas latihan untuk meningkatkan VO2 Max, [4].

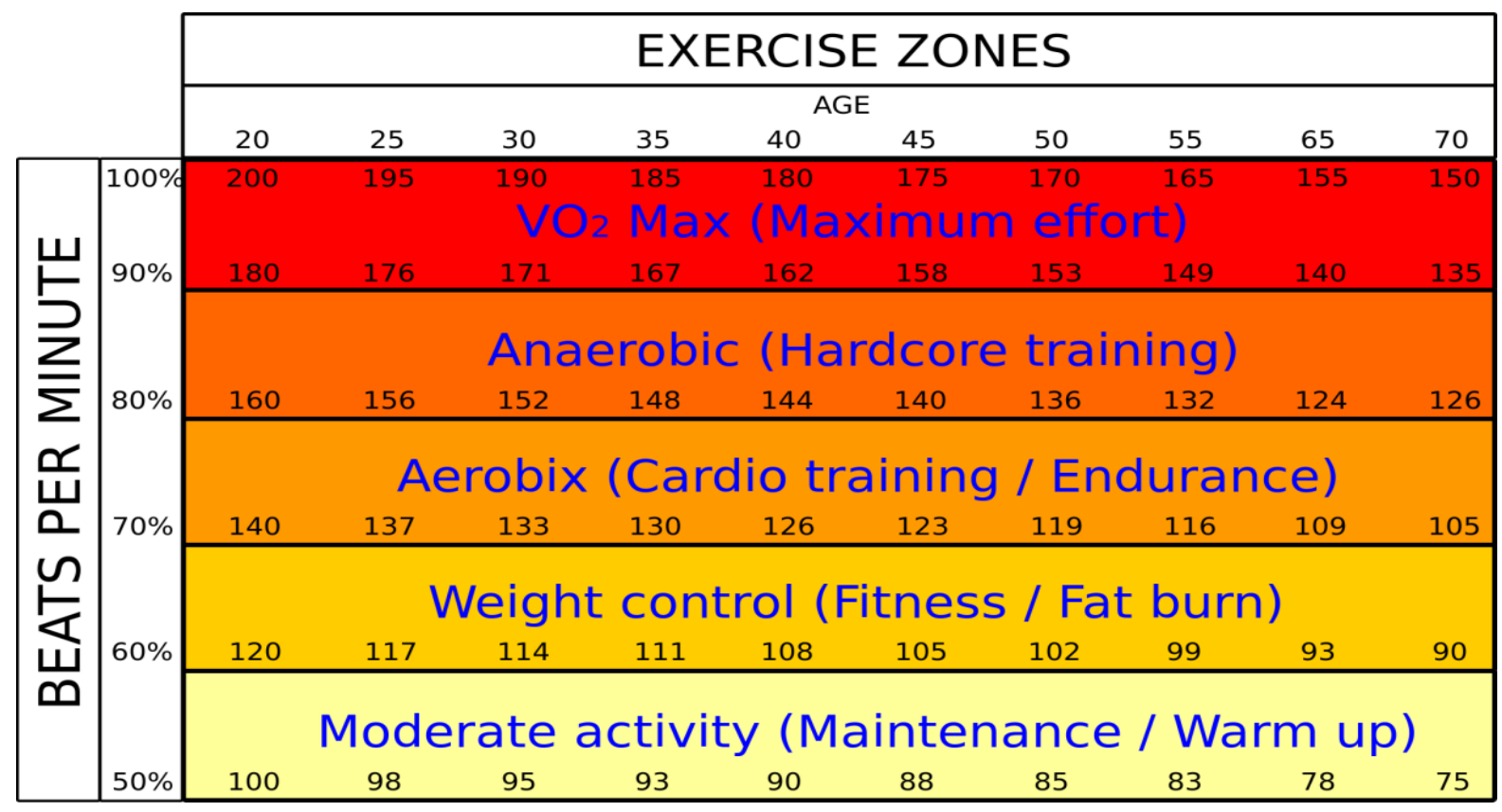

Berdasarkan, pada kutipan dan tabel 4, dapat disimpulkan bahwa meningkatnya kapasitas aerobik maksimal sebagai efek dari metode latihan bermain. Pertama, karena intensitas latihan melalui pengukuran denyut nadi yang dicapai sampel dalam setiap sesi latihan rata-rata $70 \%-80 \%$ dari denyut nadi maksimal. Kedua, sampel di dalam melakukan latihan metode bermain ini dengan penuh semangat, gembira dan motivasi tinggi. Karena metode bermain ini memiliki variasi gerak yang cukup banyak yang akan melibatkan sebagian besar otot-otot tubuh, sehingga sistem kardiovasculer terpacu secara maksimal, tanpa mengalami kelelahan yang berarti dari setiap sampel.

\section{Pengaruh Model Latihan Sirkuit Terhadap Kapasitas Aerobik Maksimal}

Hasil analisis data yang di lakukan dalam penelitian ini ternyata $\rho=0,000<\alpha 0,05$. Artinya, model latihan sirkuit dapat meningkatkan kapasitas aerobik maksimal secara bermakna. Peningkatan kapasitas aerobik maksimal sebagai efek latihan tersebut, kemungkinan disebabkan oleh beberapa faktor sebagai berikut; Pertama, Seperti halnya pada metode latihan bermain, intensitas latihan yang dicapai pada saat latihan rata-rata $70 \%-80 \%$ dari denyut nadi maksimal. Intensitas tersebut sudah masuk ke zona latihan untuk meningkatkan kapasitas aerobik maksimal $\left(\mathrm{VO}_{2}\right.$ maks). Kedua, latihan sirkuit akan melatih sebagian besar otot-otot tubuh, karena disetiap pos (stasiun) berisi bentukbentuk latihan yang berbeda atau bervariasi. Ketiga, latihan model sirkuit dalam pelaksanaanya disetiap pos lebih fokus pada otot-otot tertentu, sehingga efek latihan pada otot-otot yang terlibat dalam setiap bentuk latihan bisa lebih maksimal.

3. Perbedaan pengaruh antara model latihan bermain dan model latihan sirkuit terhadap kapasitas aerobik masimal

Berdasarkan pada hasil analisis data yang di lakukan dalam penelitian ini ternyata $\rho=0,001<$ $\alpha 0,05$. Artinya, terdapat perbedaan pengaruh antara model latihan bermain dengan model latihan sirkuit terhadap peningkatan kapasitas aerobik maksimal. Perbedaan tersebut menunjukkan bahwa model latihan sikuit lebih efektif dari pada model latihan bermain untuk meningkatkan kapasitas aerobic maksimal. Hal ini berdasarkan pada skor rata-rata model latihan sirkuit 40.6 lebih besar dari pada skor rata-rata model latihan bermain yaitu 38.8. Perbedaan pengaruh latihan ini kemungkinan disebabkan oleh beberapa faktor sebagai berikut; 
Pertama, model latihan sirkuit lebih fokus pada beberapa otot tertentu saja sesuai dengan bentuk gerakan yang dilakukan disetiap pos yang ada, sehingga efek latihan juga lebih fokus. Kedua, program latihannya seperti intensitas, repetisi, set, durasi dan rekoveri terkendali dengan baik, sehingga efek latihannya bisa lebih maksimal.

\section{Kesimpulan}

Berdasarkan beberapa hal yang diuraikan di atas, dapat disimpulkan bahwa;

1. Model latihan bermain dapat meningkatkan kapasitas aerobik maksimal, hal ini dibuktikan dengan hasil uji t $\rho=0,000<\alpha 0,05$.

2. Model latihan sirkuit dapat meningkatkan kapasitas aerobik maksimal, hal ini dibuktikan dengan hasil uji t $\rho=0,000<\alpha 0,05$.

3. Terdapat perbedaan antara model latihan bermain dengan model latihan sirkuit terhadap peningkatan kapasitas aerobik maksimal, hal ini dibuktikan dengan hasil uji t $\rho=0,001<\alpha 0,05$.

\section{Saran}

1. Untuk meningkatkan kapasitas aerobic maksimal atlet, bisa digunakan kedua macam model latihan ini,

2. Untuk mendapatkan hasil peningkatan kapasitas aerobik maksimal sesuai dengan yang diharapkan, sebaiknya memakai metode latihan yang lebih bervariasi.

\section{Referensi}

Bompa, Haff., G.G., 2009. Periodization Theory and Methodology of Training. Fifth ed. Champaign: Human Kinetics.

Donald Ary., Luchy C.Jacobs dan Asghar R., 2004. Pengantar Penelitian dalam Pendidikan. Yogyakarta: Pustaka Pelajar offset.

Harsono., 1996. Prinsip dan Metodologi Pelatihan, Jakarta: PIO-KONI Pusat,

http://hobilari.com/2014/06/04/maximum-and-target-heart-rate/

Johny Lycholat., 1989. Circutit Weight Training. Northamptonshire: Thorsons Publishing Group.

Matt Fitzgerald. 2005. How to Maximize Your VO2max Training. http://www. active.com/running/articles/how-to-maximize-your-vo2max-training

O'Connor, Lanty., 2009. Interval Training: Increase your VO2max, lactate threshold, stroke volume, and improve your cholesterol, http: //workouthacker .com/2009/10/interval-training-increaseyour-vo2max.

Robert Hockey., 1981. Physical Fitness. St. Missouri: CV. Mosby Company.

Umar., 2014. Fisiologi Olahraga. Padang: UNP Press.

UU RI No. 3 tahun 2005., 2006. Sistem Keolahragaan Nasional. Jakarta: Kemenpora. 


\title{
THE EFFECTS OF PHYSICAL EXERCISE THROUGH \\ GAME-MODEL AND CIRCUIT-MODEL EXERCISES APPROACH \\ ON THE MAXIMUM AEROBIC CAPACITY
}

(Experimental Study on Students of Faculty of Sports Science Universitas Negeri Padang)

\author{
Umar $^{1}$, Alnedral $^{1}$ \\ ${ }^{1}$ Faculty of Sports Science, Universitas Negeri Padang \\ 11umarmardesia@gmail.com, alnedral@uny.ac.id
}

\begin{abstract}
Object

The purpose of this study was to analyze the effect of effective and efficient exercise model on maximal aerobic capacity improvement.

\section{Method}

This type of research is quasi-experiments, with treatment in the form of a game model exercise and circuit model exercise. Before the treatment, there was a pre-test of Maximum Aerobic Capacity using the MSFT (Bleep test) instrument. Treatment was given 16 times with details of 3 times per week. Target population is Faculty of Sports Science students of Padang State University, while the affordable population is 30 students of Sports Education program class 2013/2014 Faculty of Sports Science Padang State University. Sampling is done by purposive sampling. Data analysis using descriptive and inferential statistics, inferential statistics using t test at significance level $\alpha 0.05$.
\end{abstract}

\section{Results}

1. The model of Game exercise gives a significant influence on the increase of Maximum Aerobic Capacity students of Faculty of Sports Science Padang State University, $(\rho=0,000<\alpha 0,05)$.

2. Circuit model exercise gives significant influence to the increase of Maximum Aerobic Capacity students of Faculty of Sports Science Padang State University, $(\rho=0,000<\alpha 0,05$.)

3. There is a significant difference of influence between the game model of exercise with the circuit model of exercise to the increase of Maximum Aerobic Capacity students of Faculty of Sports Science Padang State University, $(\rho=0.001<\alpha 0.05)$.

\section{Conclusion}

Both of the exercise models have a positive effect on maximum aerobic capacity increase. However, the data analysis shows that the circuit model exercise is more effective to increase maximum aerobic capacity.

Keywords; game model exercises, circuit model exercise, maximum aerobic capacity

\section{Introduction}

Creating athletes full of achievements, requires careful planning, as well as tiered coaching. In the Indonesian Constitution number 3 year 2005, about National Sport System, in Chapter V article 33 paragraph 2 mentioned that; "Sports achievement is a sport that nurtures and develops sportsmanship in a planned, tiered and sustainable manner through training and competition to achieve achievement with the support of science and technology athletics. [10]. Based on the quotation it can be concluded that; to create athletes with achievements the need to perform a planned coaching with the support of science and technology is essential, so that the training process can be maximized in accordance with the organs function physiologically. Without involving science and technology in the exercise process, the ability of athletes can not be increased optimally.

One of the coaching programs is through exercises, because the exercise can help athletes improve skills and achievements, especially on four aspects such as; techniques, physical conditions, 
tactics and strategies, as well as mental ". If one of these aspects is weak, it will affect other aspects, so that athletes can not perform optimally in every game. [3]. One important aspect that an athlete must possess, is the aspect of physical condition which is a fundamental aspect to support another aspects. Elements of physical conditions; strength, speed, endurance, agility, explosive power, balance and coordination. Any elements of physical condition an athlete should possess, it depends on the sport he follows, because each sport has its own characteristics. [1].

On sports such as ; medium to long distance run, swimming to 100 meters and up, martial arts, endurance is the main physical components an athlete must have, especially aerobics endurance, because it is needed to be able to perform activities in a relatively long time. Aerobics endurance is the ability of the body to perform activities in a long time without experiencing significant fatigue by using aerobic energy supply.

An aerobic endurance or often called cardio-respiratory endurance is a quality of how the body as a whole supports physical activity and can inhibit the cause of fatigue ". [6]. While Robert Hoccey says that; " cadiovascular endurance can be defined as the ability to perform continuous work in performing the tasks of a group of muscles at a relatively long time. [8]. The level of this aerobic endurance will be affected by the level of $\mathrm{VO} 2$ max or known as the maximum aerobic capacity. The level of maximum aerobic capacity is affected by organic components such as; lungs, heart, blood vessels, and blood quality (hemoglobin) and skeletal muscles that will consume oxygen for aerobic energy metabolism processes, resulting in energy for cellular work, including muscle cells [9].

A high maximum aerobic capacity (VO2 max), not only required by athletes when they are exercising or competing, but also needed when they are doing recovery. The defeats often experienced by an athlete in a match, one of which is due to their low aerobic capacity, this can be seen in every game such as a martial arts [9]. usually, athletes appear prime and violent at the beginning of the round, but in the next round, their tendency decreases, it is evident that they are not supported by maximum aerobic capacity (VO2max), so the recovery process (recovery) is not running perfectly.

Based on the observations done on students of Faculty of Sports Science in Universitas Negeri Padang, there are still many students who have a low aerobic capacity. This is reflected in each of the following practice classes, as well as doing exercises, many students experienced fatigue faster. The low level of maximum aerobic capacity of students in Faculty of Sports Science Universitas Negeri Padang, who are being prepared as a coach who will be on duty field in accordance with his profession as a trainer. In addition, the students of Faculty of Sports Science Universitas Negeri Padang are mostly athletes who are still actively participating in various sports events, either sporting the Provincial Sports Week (Porvrop), National Championships (National Championship), National Sports Week (PON), as well as regional championships such as SEA Games, caused by many factors, one of which is the material of the training program provided by the trainer,

\section{Formulation of the problem}

The formulation of the problem is;

1. Can the model of exercise play increase maximum aerobic capacity?

2. Will the circuit training model increase maximum aerobic capacity?

3. Is there any difference in effect between the model of exercise play and the circuit training model on maximal aerobic capacity improvement?

\section{Research purposes;}

The purpose of this study is to analyze;

1. Influence of play practice model to maximal aerobic capacity,

2. Effect of circuit training model on maximal aerobic capacity,

3. Differences in influence between the model of playing exercises with the model of the exercise of the circuit to the maximum aerobic capacity.

\section{Benefits of research}

The research benefits are as follows;

1. Trainer, as a guide in making physical exercise program,

2. Student / Athlete, as knowledge in performing the right physical exercise, 
3. Researchers, increasing the insight of Science and Technology in supporting the profession as educators and trainers.

\section{Methodology}

This type of research is quasi experiment (quasi experiment). Quasi experiment is a type of experimental research in which the researcher can not fully control all variables that may affect the dependent variable. [2]. The research was conducted in the laboratory of the Faculty of Sport Science, State University of Padang. The data collection process is done in 2 (two) main stages. The first stage of data collection on the maximum aerobic capacity. The second stage is giving the treatment of exercise model and circuit training model as much as 16 times of practice, ( 3 times per week).

The design of this research is; the two groups pre test and post test design. Population in this research, is student of Faculty of Sport Science Universitas Negeri Padang as target population (target population). While the affordable population (affordable population) is a student Faculty of Sport Science Negeri Padang Sport Education program class of 2013/2014 registered in the semester of July December 2013/2014. While the sample used in this study are 30 students with a purposive sampling technique.

The research instrument for measuring the maximum aerobic capacity is Bleep test (MSFT). Data analysis using $t$ test with significance level $\alpha=0,05$.

\section{Research result}

\section{A. Data Description}

\section{Initial Data Aerobic Capacity Maximum Group of Play Training Methods}

Based on the results of descriptive data analysis of 15 people group exercise training method, obtained the highest score 47.1, lowest score 30.6, average score 37.7, span 16.5. For more details can be seen in the following table:

Table 1. Initial Data Aerobic Capacity Maximum Group of Play Training Methods

\begin{tabular}{|c|c|c|c|}
\hline No & Interval class & (Fa) & (Fr) \\
\hline 1 & $30.6-33.4$ & 4 & 27 \\
\hline 2 & $33.5-35.7$ & 2 & 13 \\
\hline 3 & $35.8-38.5$ & 2 & 13 \\
\hline 4 & $38.6-41.2$ & 4 & 27 \\
\hline 5 & $41.3-47.5$ & 3 & 20 \\
\hline & Total & 15 & $100 \%$ \\
\hline
\end{tabular}

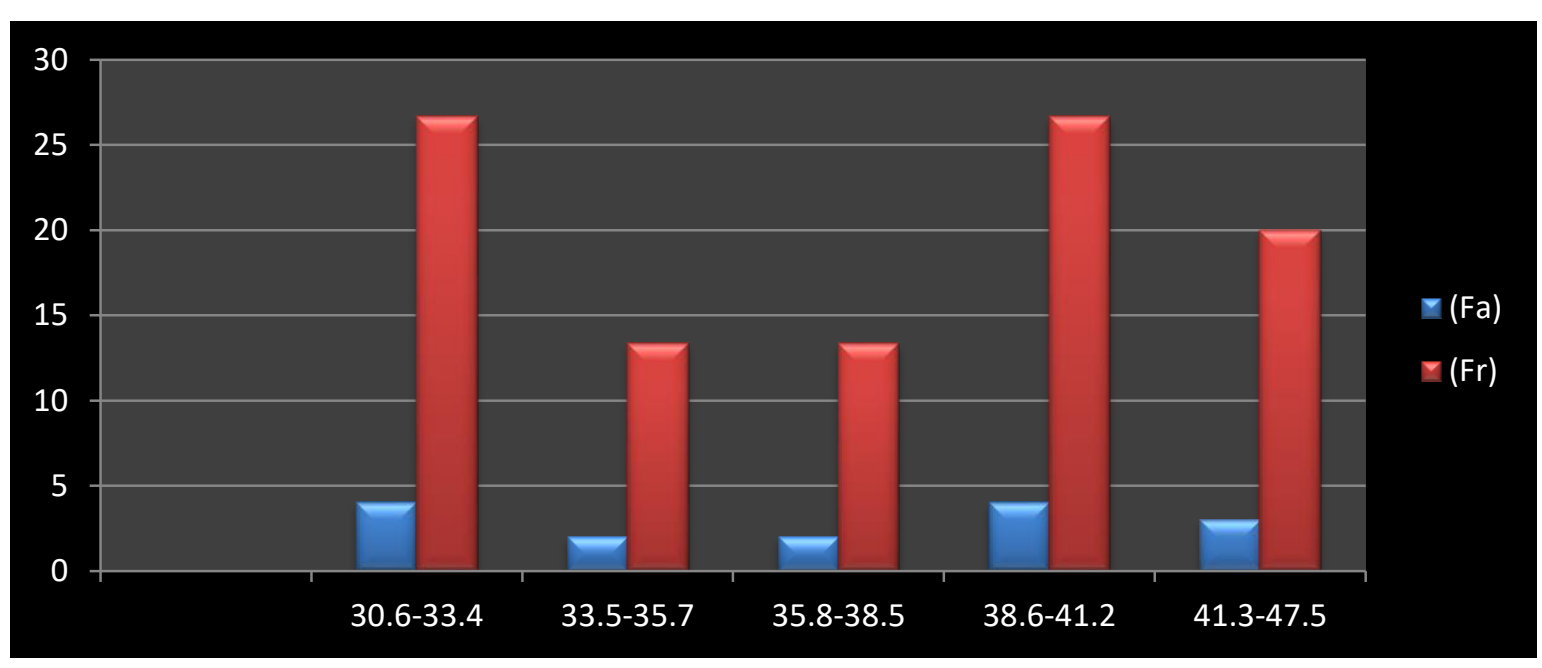

Fig. 1. Histogram frequency score Maximum Aerobic Capacity group of Play Training Methods 


\section{Initial Data Aerobic Capacity Maximum Group of Circuit Training Methods}

Based on the results of descriptive data analysis of 15 people group of exercise training methods, obtained the highest score 46.8, lowest score 30.6, average score 37.7, rantangan 16.2 and standard deviation 5.03. For more details can be seen in the following table:

Table 2. Initial Data Aerobic Capacity Maximum Group of Circuit Training Methods

\begin{tabular}{|c|c|c|c|}
\hline No & Interval Class & (Fa) & (Fr) \\
\hline 1 & $30.6-33.4$ & 3 & 20 \\
\hline 2 & $33.5-35.7$ & 4 & 27 \\
\hline 3 & $35.8-39.5$ & 2 & 13 \\
\hline 4 & $39.6-41.2$ & 3 & 20 \\
\hline 5 & $41.3-46.8$ & 3 & $100 \%$ \\
\hline & Total & 15 & \\
\hline
\end{tabular}

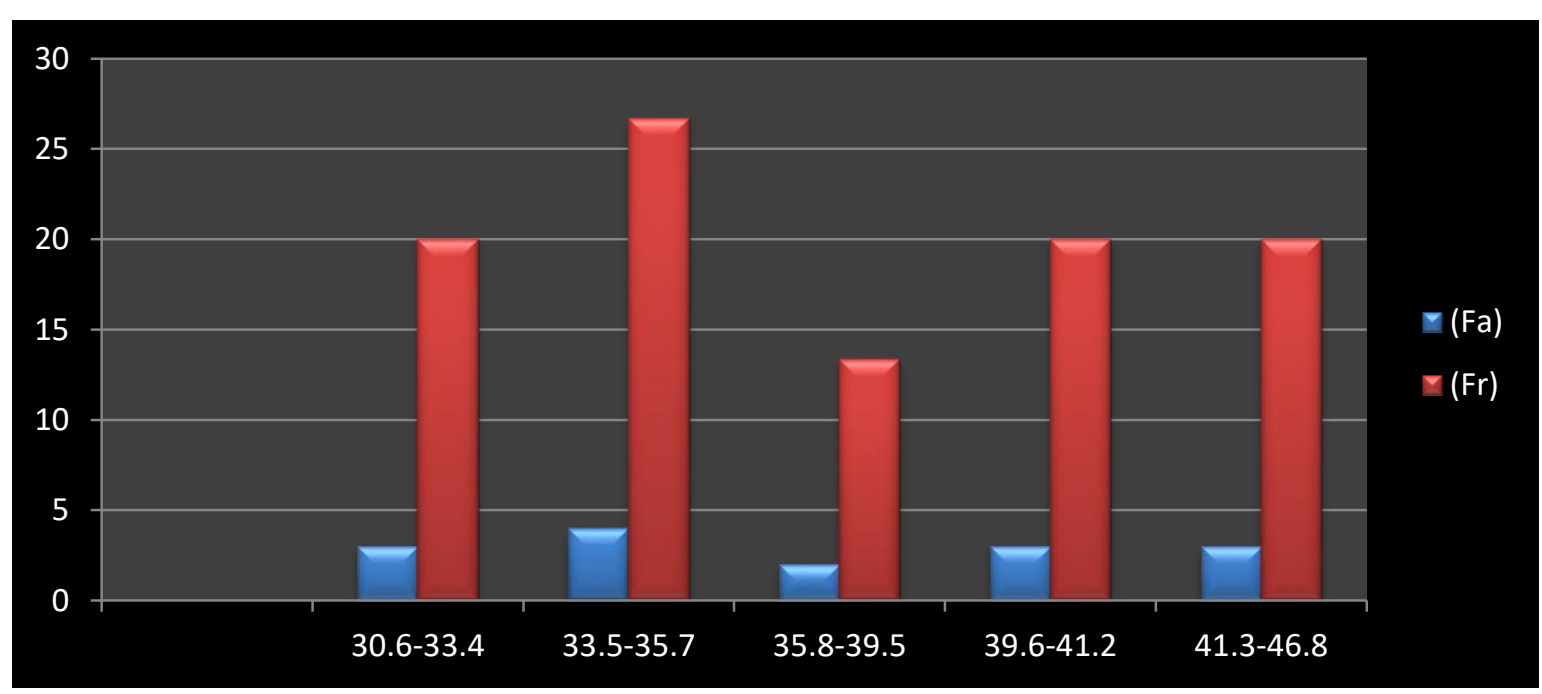

Fig. 2. Histogram frequency score Maximum Aerobic Capacity group of Play Training Methods

\section{Final Data Aerobic Capacity Maximum Group of Play Training Methods}

Based on the results of descriptive data analysis of 15 people group of exercise training methods, obtained the highest score 48.4, the lowest score 32.5, the average score of 38.8, rantangan 15.9 and standard deviation 4.67 . For more details can be seen in the following table:

Table 3. Final Data Aerobic Capacity Maximum Group of Play Training Methods

\begin{tabular}{|c|c|c|c|}
\hline No & Interval Class & (Fa) & (Fr) \\
\hline 1 & $32.9-35.6$ & 4 & 27 \\
\hline 2 & $35.7-38.4$ & 2 & 13 \\
\hline 3 & $38.5-40.3$ & 3 & 20 \\
\hline 4 & $40.4-42.7$ & 3 & 20 \\
\hline 5 & $42.8-48.5$ & 3 & 20 \\
\hline & Total & 15 & $100 \%$ \\
\hline
\end{tabular}




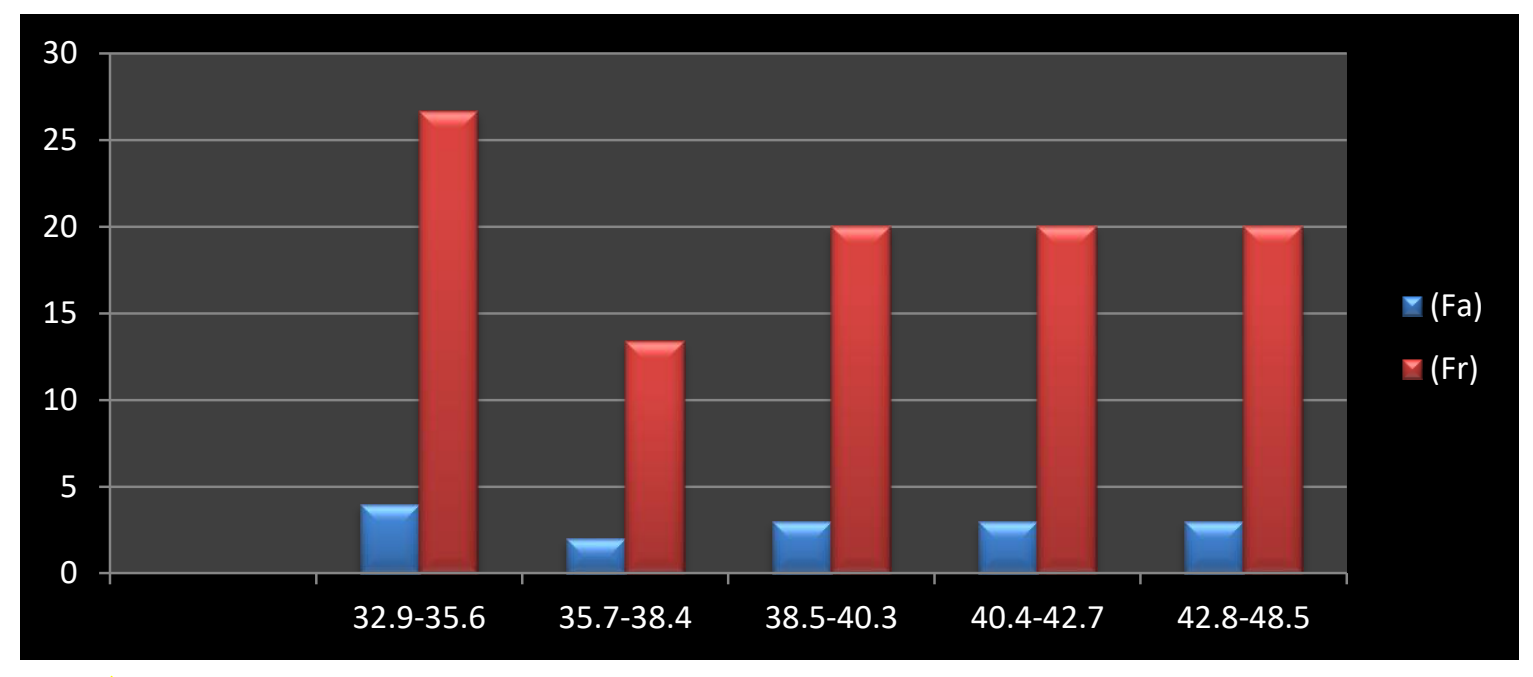

Fig. 3. Histogram frequency score Maximum Aerobic Capacity group of Play Training Methods

\section{Final Data Aerobic Capacity Maximum Group of Circuit Training Methods}

Based on the results of descriptive data analysis of 15 people group exercise circuit method, obtained the highest score 49.0, the lowest score 34.3, the average score 40.6, rantangan 14.7 and standard deviation 4.56. For more details can be seen in the following table:

Table 4. Final Data Aerobic Capacity Maximum Group Circuit Exercise Method

\begin{tabular}{|c|c|c|c|}
\hline No & Interval Class & (Fa) & (Fr) \\
\hline 1 & $34.3-35.8$ & 3 & 20 \\
\hline 2 & $35.9-37.6$ & 1 & 7 \\
\hline 3 & $37.7-40.4$ & 3 & 20 \\
\hline 4 & $40.5-42.7$ & 3 & 20 \\
\hline 5 & $42.8-50.00$ & 5 & 33 \\
\hline & Total & 15 & $100 \%$ \\
\hline
\end{tabular}

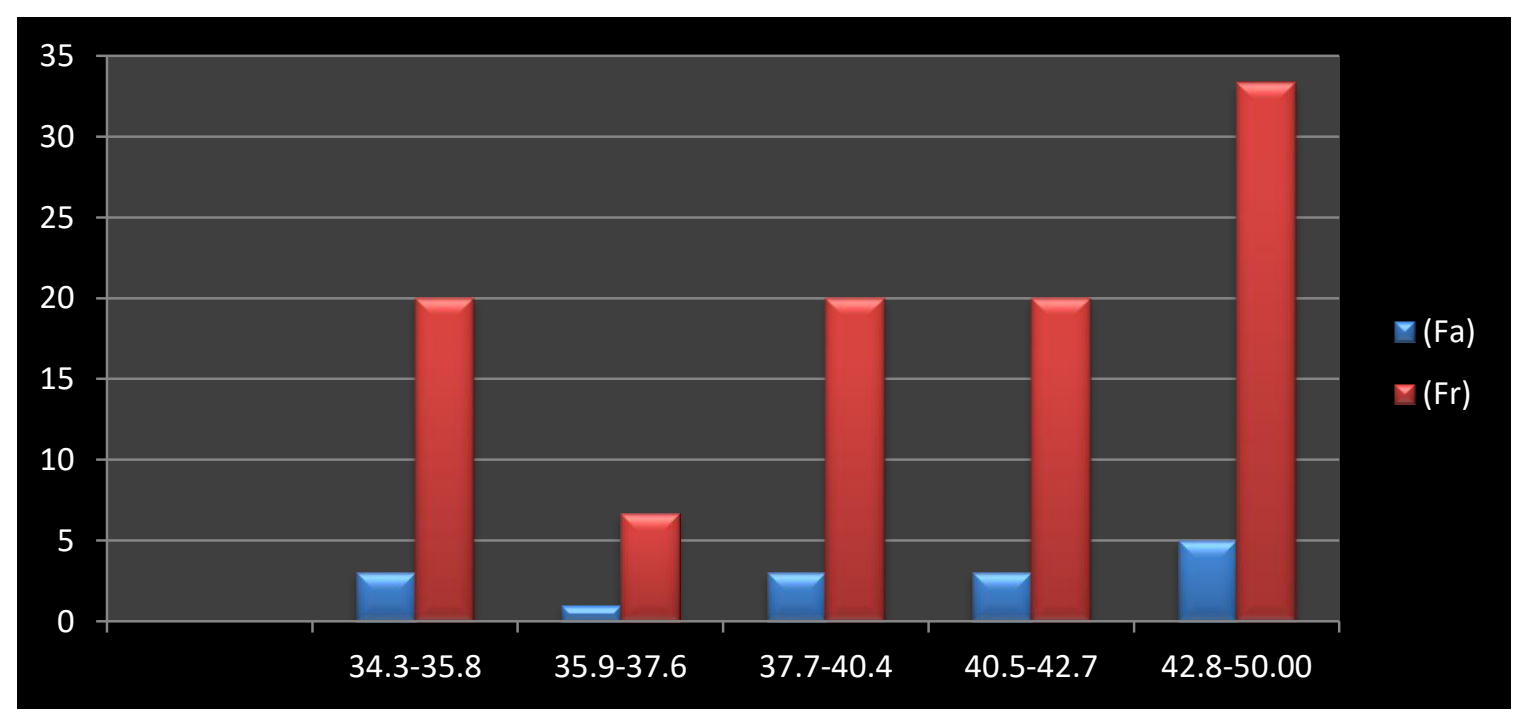

Fig. 4. Histogram frequency score Maximum Aerobic Capacity group of Play Training Methods 


\section{B. Hypothesis Testing}

\section{First Hypothesis}

The hypothesis proposed in this study is "There is an influence of the exercise model of play on the maximum capacity aerobic. Based on result of data analysis turns out $\rho=0,000<\alpha=0,05$. Thus it can be concluded that there is influence of the method of playing exercises on aerobic aerobic athlete's capacity. For more details can be seen in the following table;

Table 5. Test Result T Test Data Pretest and Posttest Play Group

\begin{tabular}{|c|c|c|c|c|c|c|c|c|c|}
\hline & \multicolumn{5}{|c|}{ Paired Differences } & \multirow{3}{*}{$\mathrm{t}$} & \multirow{3}{*}{ df } & \multirow{3}{*}{$\begin{array}{l}\text { Sig. (2- } \\
\text { tailed) }\end{array}$} \\
\hline & & \multirow[t]{2}{*}{ Mean } & \multirow[t]{2}{*}{$\begin{array}{c}\text { Std. } \\
\text { Deviation }\end{array}$} & \multirow[t]{2}{*}{$\begin{array}{l}\text { Std. } \\
\text { Error }\end{array}$} & \multicolumn{2}{|c|}{$\begin{array}{l}\text { 95\% Confidence } \\
\text { Interval of the } \\
\text { Difference }\end{array}$} & & & \\
\hline & & & & & Lower & Upper & & & \\
\hline Pair 1 & $\begin{array}{l}\text { Posttest } \\
\text { Pretest }\end{array}$ & 1.1933 & .5147 & .1329 & .9083 & 1.4784 & 8.979 & 14 & .000 \\
\hline
\end{tabular}

Thus the hypothesis proposed in this study that says there is influence of the method of playing exercises on aerobic aerobic capacity of athletes is acceptable.

\section{Second Hypothesis}

The hypothesis proposed in this study is "There is influence of Circuit training model to the maximum aerobic capacity. Based on result of data analysis turns out $\rho=0,000<\alpha 0,05$. Thus it can be concluded that there is influence of circuit training method on aerobic aerobic capacity of athlete. For more details can be seen in the following table;

Table 6. Test Result Analysis of Data Pretest and Posttest of Circuit Group

\begin{tabular}{|c|c|c|c|c|c|c|c|c|c|}
\hline & & & Pair & Differe & & & & & \\
\hline & & Mean & $\begin{array}{c}\text { Std. } \\
\text { Deviation }\end{array}$ & $\begin{array}{l}\text { Std. } \\
\text { Error }\end{array}$ & $\begin{array}{r}95 \% \text { Co } \\
\text { Interva } \\
\text { Diffe }\end{array}$ & $\begin{array}{l}\text { fidence } \\
\text { of the } \\
\text { ence }\end{array}$ & $\mathrm{t}$ & $d f$ & $\begin{array}{l}\text { Sig. (2- } \\
\text { tailed) }\end{array}$ \\
\hline & & & & & Lower & Upper & & & \\
\hline Pair 1 & $\begin{array}{c}\text { Posttest } \\
\text { Pretest }\end{array}$ & 2.9000 & .7521 & 1942 & 2.4835 & 3.3165 & 14.933 & 14 & .000 \\
\hline
\end{tabular}

Thus the hypothesis proposed in this study that says there is influence of the method of circuit training on aerobic aerobic capacity of athlete is acceptable.

\section{Third Hypothesis}

The hypothesis proposed in this study is "There is a difference in the effect between the model of playing practice and the circuit training model on the aerobic capacity of the mask. Based on result of data analysis turns out $\rho=0,001<\alpha 0,05$. Thus it can be concluded that there is a difference of influence between the method of playing exercises and the method of circuit training on aerobic aerobic athlete's capacity. For more details can be seen in the following table; 
Table 7. Result of $t$ Test Analysis Posttest Data between Play Group and Circuit Group

\begin{tabular}{|c|c|c|c|c|c|c|c|c|c|}
\hline & & \multicolumn{5}{|c|}{ Paired Differences } & \multirow{3}{*}{$\mathrm{t}$} & \multirow{3}{*}{ df } & \multirow{3}{*}{$\begin{array}{l}\text { Sig. (2- } \\
\text { tailed) }\end{array}$} \\
\hline & & \multirow[t]{2}{*}{ Mean } & \multirow[t]{2}{*}{$\begin{array}{c}\text { Std. } \\
\text { Deviation }\end{array}$} & \multirow[t]{2}{*}{$\begin{array}{l}\text { Std. } \\
\text { Error }\end{array}$} & \multicolumn{2}{|c|}{$\begin{array}{l}95 \% \text { Confidence } \\
\text { Interval of the } \\
\text { Difference }\end{array}$} & & & \\
\hline & & & & & Lower & Upper & & & \\
\hline Pair 1 & $\begin{array}{c}\text { Posttest } \\
\text { Sirkuit } \\
\text { Posttest } \\
\text { Bermain }\end{array}$ & 1.6571 & 1.3971 & .3734 & .8505 & 2.4638 & 4.438 & 13 & .001 \\
\hline
\end{tabular}

Thus the hypothesis proposed in this study that says there is a difference in the effect between the method of play practice and the method of circuit training on aerobic aerobic capacity of athlete is acceptable, and if seen from the difference of mean score, then the circuit training model is more effective to increase maximum aerobic capacity.

\section{Discussion}

\section{Influence of Model of Playing Exercise to Maximum Aerobic Capacity}

The result of data analysis done in this research turns out $\rho=0,000<\alpha 0,05$. That is, the model of playing practice can increase the maximum aerobic capacity significantly. Increased maximum aerobic capacity as a result of the exercise, possibly caused by several factors as follows; First, the intensity of exercise averages $70 \%-80 \%$ of the maximum pulse rate. The intensity has already entered the training zone to increase maximum aerobic capacity (VO2 max). This is as it is said by; Matt Fitzgerald that; Research suggests that vigorous-intensity exercise (60-84\% oxygen consumption reserve ( $\left.\mathrm{V}^{\circ} \mathrm{O} 2 \mathrm{R}\right)$ ) results in greater increases in aerobic capacity than moderateintensity exercise (40-59\% V O2R). [6].

Research shows that a strong / high intensity exercise $(60-84 \%$ of reserve oxygen consumption $\left.\left(\mathrm{V}^{\circ} \mathrm{O} 2 \mathrm{R}\right)\right)$ results in greater increases in aerobic capacity than moderate exercise intensity (40-59\% V'O2R). This is reinforced by Lanty O'Connor, (2009) that the effects of exercise exercise to increase maximum aerobic capacity (VO2 max) can already occur at $70 \%$ exercise intensity. For more details can be seen in table 4.

Tabel 8. Zona intensitas latihan untuk meningkatkan VO2 Max, [4].

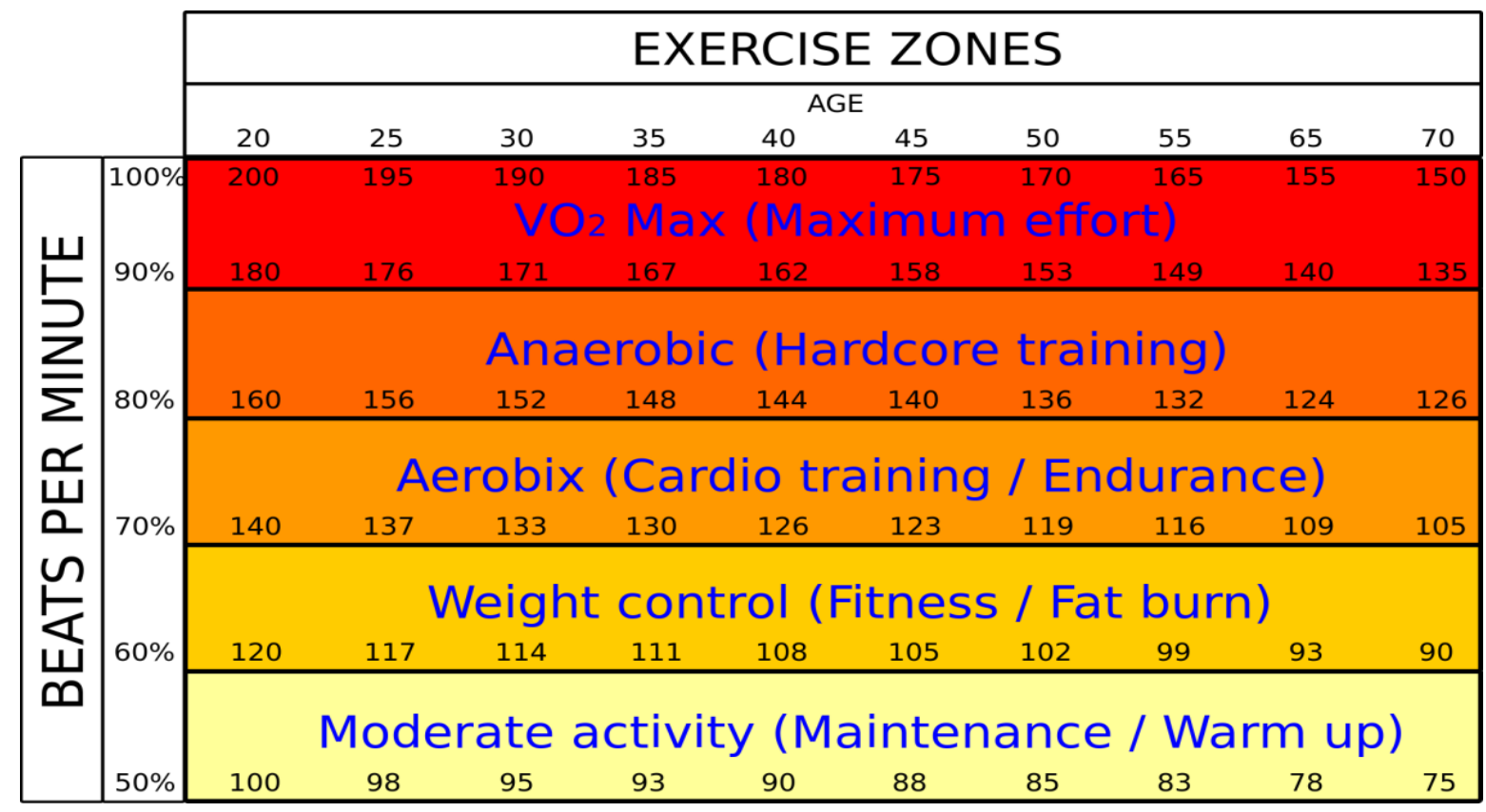


Based on the quote and table 4, it can be concluded that the increased aerobic capacity is maximal as the effect of the training method of play. First, because the intensity of the exercise through pulse measurements achieved in each training session averaged $70 \%-80 \%$ of the maximum pulse. Secondly, the samples in the exercise of this play method are full of vigor, excitement and high motivation. Because this method of play has considerable motion variations that will involve most of the muscles of the body, so the cardiovascular system is maximized, without experiencing significant fatigue from each sample.

\section{Effect of Circuit Exercise Model on Maximum Aerobic Capacity}

The result of data analysis done in this research turns out $\rho=0,000<\alpha 0,05$. That is, the circuit training model can increase the maximum aerobic capacity significantly. Increased maximum aerobic capacity as a result of the exercise, possibly caused by several factors as follows; First, As with the method of exercise, the intensity of the exercise achieved during the exercise is $70 \%-80 \%$ of the maximum pulse rate. The intensity has already entered the training zone to increase maximum aerobic capacity (VO2 max). Second, circuit training will train most of the muscles of the body, because each station (station) contains different or varied forms of exercise. Third, the exercise circuit model in the implementation of each post is more focused on certain muscles, so the effect of exercise on the muscles involved in each form of exercise can be more leverage.

3. Differences in influence between the model of exercise play and the circuit training model of the aerobic capacity of the masses

Based on the results of data analysis performed in this study was $\rho=0.001<\alpha 0.05$. That is, there is a difference of influence between the model of exercise play with circuit training model to increase the maximum aerobic capacity. These differences indicate that the model of the cyclical exercise is more effective than the exercise-training model to increase maximum aerobic capacity. This is based on the average score of the circuit training model 40.6 is greater than the average score of the exercise-training model is 38.8 . The difference in the effect of this exercise may be due to several factors as follows;

First, the circuit training model focuses more on certain muscles only according to the shape of the movements performed in each post, so that the exercise effect is also more focused. Second, the training program such as intensity, repetition, set, duration and well controlled recovery, so that the effects of exercise can be more leverage.

\section{Conclusion}

Based on some of the things described above, it can be concluded that;

1. The model of playing exercises can increase the maximum aerobic capacity, as evidenced by the results of t-test $=0,000<\alpha 0.05$.

2. Circuit training model can increase maximum aerobic capacity, this is proved by the result of $t$ test $=$ $0,000<\alpha 0,05$.

3. There is a difference between the exercise model and the circuit training model for maximal aerobic capacity improvement, as evidenced by the result of $\mathrm{t}$-test $=0.001<\alpha 0.05$.

\section{Suggestion}

1. To increase maximum aerobic capacity of athlete, can be used both kinds of model of this exercise,

2. To get maximum aerobic capacity increase as expected, it is better to use more varied training methods. 


\section{Referensi}

Bompa, Haff., G.G., 2009. Periodization Theory and Methodology of Training. Fifth ed. Champaign: Human Kinetics.

Donald Ary., Luchy C.Jacobs dan Asghar R., 2004. Pengantar Penelitian dalam Pendidikan. Yogyakarta: Pustaka Pelajar offset.

Harsono., 1996. Prinsip dan Metodologi Pelatihan, Jakarta: PIO-KONI Pusat,

http://hobilari.com/2014/06/04/maximum-and-target-heart-rate/

Johny Lycholat., 1989. Circutit Weight Training. Northamptonshire: Thorsons Publishing Group.

Matt Fitzgerald. 2005. How to Maximize Your VO2max Training. http://www. active.com/running/articles/how-to-maximize-your-vo2max-training

O'Connor, Lanty., 2009. Interval Training: Increase your VO2max, lactate threshold, stroke volume, and improve your cholesterol, http: //workouthacker .com/2009/10/interval-training-increaseyour-vo2max.

Robert Hockey., 1981. Physical Fitness. St. Missouri: CV. Mosby Company.

Umar., 2014. Fisiologi Olahraga. Padang: UNP Press.

UU RI No. 3 tahun 2005., 2006. Sistem Keolahragaan Nasional. Jakarta: Kemenpora. 
